\title{
Studies on In-Vitro Antiglycation Potential of Some Indigenous Antidiabetic Plants
}

\author{
Mangesh Bhutkar*, Somnath Bhinge, Dheeraj Randive, Ganesh Wadkar and Sachin Todkar \\ Rajarambapu College of Pharmacy, Indiaa
}

Submission: June 17, 2017; Published: November 14, 2017

*Corresponding author: Mangesh Bhutkar, Rajarambapu College of Pharmacy, Kasegaon, Maharashtra, 415 404, India, E-mail: mangesh_bhutkar@rediffmail.com

\begin{abstract}
The in vitro antiglycation activity of extracts of some traditional antidiabetic plants was studied by determining the degree of nonenzymatic hemoglobin glycosylation. The best concentration and time required to incubate glucose with hemoglobin was estimated. Thereafter, the glycosylation degree of hemoglobin in the presence of plant extracts under study at different concentrations and in their absence was measured calorimetrically. The inhibitory affect on glycosylation of hemoglobin at the four concentrations namely $250 \mu \mathrm{g} / \mathrm{ml}$, $500 \mu \mathrm{g} / \mathrm{ml}, 750 \mu \mathrm{g} / \mathrm{ml}$ and $1000 \mu \mathrm{g} / \mathrm{ml}$ were determined as follows: for A. lebbeck $19.08 \%, 29.22 \%, 37.86 \%$ and $48.55 \%$, B. aristata; $29.66 \%$, $37.05 \%, 49.0 \%, 56.17 \%$, M. pruriens; $45.83 \%, 58.73 \%, 70.14 \%$, and $75.60 \%$ respectively. The studies demonstrated that non-enzymatic nature of hemoglobin glycosylation could be effectively inhibited by the extracts of M. pruriens, B. aristata and A. lebbeck at a desirable concentration.
\end{abstract}

Keywords: Antiglycation, Hemoglobin, Inhibition, Non-enzymatic

Abbreviations: AGEs: Advanced Glycation End products; BSS: British Standard Sieve.

\section{Introduction}

Diabetes mellitus is a complex chronic metabolic disorder that is a major source of ill health worldwide. It is characterized by hyperglycemia and disturbances of carbohydrate, protein and fat metabolisms secondary to an absolute or relative lack of hormone insulin [1]. The elevated blood glucose level is considered the principal cause of complications in diabetes mellitus [2]. Diabetic complications usually arise as a result of non-enzymatic protein glycation, which leads to the formation of heterogeneous, toxic and antigenic advanced glycation end products (AGEs) [3]. The accumulation of AGEs in vivo has been considered to play a major role in the pathogenic process of diabetes and its complications, including neuropathy, nephropathy, retinopathy, cataract and in other health disorder such as Alzheimer's disease and aging [4, 5,6]. Thus, the investigation of compounds with an AGEs inhibitor activity, would certainly offer a potential therapeutic approach for the prevention of diabetes or other pathogenic complications. As currently, there is growing interest in herbal remedies due to the side effects associated with the oral hypoglycemic agents for the treatment of diabetes mellitus; it was decided to study the effect of extracts of some indigenous plants known for their antidiabetic activity namely A. lebbeck, B. aristata and $M$. pruriens on non-enzymatic glycosylation of hemoglobin. Albizzia lebbeck Benth. (Family: Leguminosae) is a deciduous tree with compound leaves, flat oblong fruits, round cream colored seeds, grows wild. Barks are used in toothache and diseases of the gum.

Decoction of the leaves and barks are protective against bronchial asthma and other allergic disorders. Barks and seeds are astringent and are given in piles and diarrhea. Ethanolic extract of pods possesses antiprotozoal, hypoglycemic and anticancer properties [7]. Berberis aristata DC. (Family: Berberidaceae) is used in Ayurveda medicines from very long time. This plant has been considered as a valuable medicine for the treatment of remittent fevers, oxidative stress and used as a cooling laxative to children and as a tonic remedy for liver and heart.

It exhibits febrifugal, hypotensive, immuno-stimulating, anti-inflammatory, antidiabetic, antimicrobial, antiprotozoal, anticholinergic and antiarrhythmic activities [8]. Mucuna pruriens Linn. (Family: Fabaceae) is one of the popular drug in Ayurvedic system of medicine [9]. Various preparations from the seeds of this plant are used for the management of several free radical mediated diseases such as ageing, rheumatoid arthritis, 
diabetes, atherosclerosis, male infertility and nervous disorders $[10,11]$.

\section{Materials and Methods}

\section{Plant material}

The bark of A. lebbeck and seeds of M. pruriens were collected from local areas of Karad, whereas the roots of B. aristata were purchased from local market. The plant material was further identified and authenticated by the Department of Botany, Science College, Karad. The bark of A. lebbeck, roots of B. aristata and the seeds of $M$. pruriens were cleaned, dried in a hot air oven $\left(50{ }^{\circ} \mathrm{C}\right)$, powdered, passed through 60 mesh sieve (BSS) and stored in an airtight container at $4{ }^{\circ} \mathrm{C}$ till further use.

\section{Chemicals}

Hemoglobin was purchased from Sigma Aldrich, USA. All the chemicals used in the study were of extra pure analytical grade.

\section{Preparation of plant extracts}

Aqueous extracts were prepared by extracting the powders of bark of A. lebbeck, roots of B. aristata and the seeds of $M$. pruriens with hot water $\left(70{ }^{\circ} \mathrm{C}\right)$ in a mechanical shaker $(24 \mathrm{~h})$, filtered and freeze dried.

\section{Determining the best condition for hemoglobin glycosylation}

To find the best glucose concentration, hemoglobin $5 \mathrm{~g} / 100 \mathrm{ml}$ in $0.01 \mathrm{M}$ phosphate buffer, $\mathrm{pH} 7.4$ was incubated with different concentrations of glucose [12]. The extent of glycosylation was measured by colorimetric method. Thereafter, to find the most useful time for glycosylation, hemoglobin $5 \mathrm{~g} / 100 \mathrm{ml}$ with the best concentration of glucose was incubated at different times and the amount of glycosylation was measured.

\section{Assay}

$1 \mathrm{ml}$ of hemoglobin solution $5 \mathrm{~g} / 100 \mathrm{ml}$ and $1 \mathrm{ml}$ of the solution containing glucose $2 \mathrm{~g} / 100 \mathrm{ml}$ and Gentamycin $20 \mathrm{mg} / 100 \mathrm{ml}$ in $0.01 \mathrm{M}$ phosphate buffer, $\mathrm{pH} 7.4$ were incubated in the dark at room temperature. Then, the glycosylation degree of hemoglobin in the presence of different concentration of plant extracts and their absences were measured by the colorimetric method.

\section{Results and Discussion}

To find the inhibitory effects of selected plant extracts on glycosylation of hemoglobin, initially hemoglobin $5 \mathrm{~g} / 100 \mathrm{ml}$ was incubated in the presence of different concentrations of glucose and then the degree of glycosylation was measured by the colorimetric method. It was observed that up to the concentration of $2 \mathrm{~g} / 100 \mathrm{ml}$ stock solution of glucose, the amount of glycosylation increased linearly (Figure 1). So as to find the suitable time for incubation in this study, hemoglobin $5 \mathrm{~g} / 100 \mathrm{ml}$ was incubated in the presence of glucose $2 \mathrm{~g} / 100 \mathrm{ml}$ at different times and the degree of glycosylation was measured by the colorimetric method.

The results showed that glycosylation increased up to the time of $72 \mathrm{~h}$ linearly and therefore, $72 \mathrm{~h}$ was chosen as the best time for this study (Figure 1). Different concentrations of the plant extracts were used in the study viz. $250 \mu \mathrm{g} / \mathrm{ml}$, $500 \mu \mathrm{g} / \mathrm{ml}, 750 \mu \mathrm{g} / \mathrm{ml}$ and $1000 \mu \mathrm{g} / \mathrm{ml}$. The inhibitory effects on glycosylation of hemoglobin at these concentrations were estimated as $19.08 \%, 29.22 \%, 37.86 \%$ and $48.55 \%$, for $A$. lebbeck extracts. For B. aristata it was observed as $29.66 \%, 37.05 \%$, $49.0 \%, 56.17 \%$, whereas for $M$. pruriens extract the inhibitory effects on hemoglobin glycosylation were observed as $45.83 \%$, $58.73 \%, 70.14 \%$, and $75.60 \%$ at a concentration of $250 \mu \mathrm{g} / \mathrm{ml}$, $500 \mu \mathrm{g} / \mathrm{ml}, 750 \mu \mathrm{g} / \mathrm{ml}$ and $1000 \mu \mathrm{g} / \mathrm{ml}$ respectively.
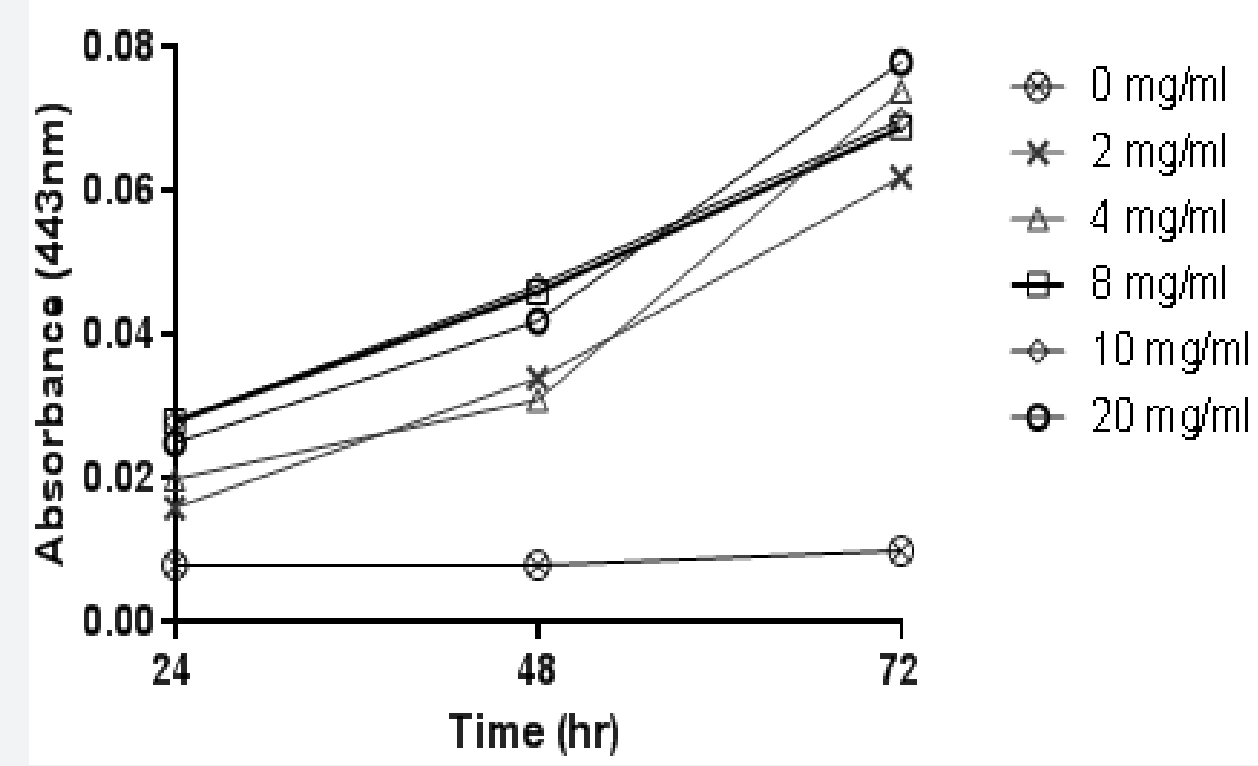

Figure 1: $1 \mathrm{ml}$ of hemoglobin solution $5 \mathrm{~g} / 100 \mathrm{ml}$ and $1 \mathrm{ml}$ of the solution containing different concentrations of glucose in $0.01 \mathrm{M}$ phosphate buffer, $\mathrm{pH} 7.4$ were incubated at room temperature at different time intervals. 


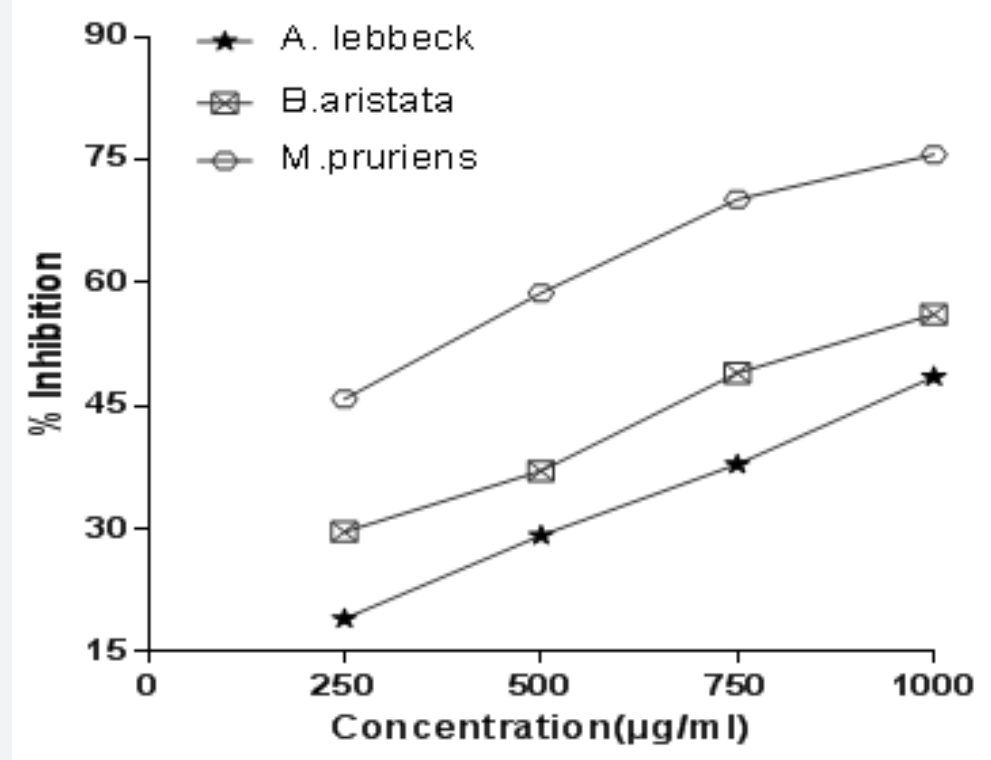

Figure 2: Inhibition of Non-enzymatic glycosylation of hemoglobin by selected plant extracts.

Increased concentration of glucose in the blood as observed in diabetes mellitus leads to its binding to hemoglobin and other plasma proteins which may result in the formation of the reactive oxygen species. Plant extracts may play an important role in the inhibition of the glycosylation end products. Our studies revealed that glycosylation of hemoglobin increases markedly on its incubation with the increasing concentration of the glucose $(2 \mathrm{mg}$, $4 \mathrm{mg}, 8 \mathrm{mg} 10 \mathrm{mg}$ and $20 \mathrm{mg}$ ) over a period of $72 \mathrm{hrs}$ (Figure 1). However, the plant extracts promisingly inhibited the glycosylation of hemoglobin as shown in (Figure 2).

The results of the studies clearly demonstrated that non-enzymatic nature of hemoglobin glycosylation could be effectively inhibited by the extracts of M. pruriens, B. aristata and $A$. lebbeck at a desirable concentration. Amongst the plant extracts studied, $M$. pruriens exhibited higher inhibition of glycosylation indicating that the extract of $M$. pruriens decreases the formation of the glucose- hemoglobin complex and thus amount of free hemoglobin increases. The vivo effect should be investigated so that it can be utilized to prevent or treat complication associated with diabetes.

\section{Conflict of Interest Statement}

We declare that we have no conflict of interest.

\section{Acknowledgement}

The authors are grateful to the Principal, Govt. College of Pharmacy, Karad for providing all the research facilities.

\section{References}

1. Bhutkar MA, Bhise SB (2011) Spices and condiments in the management of Diabetes mellitus. Res J Pharm Technol 4(1):1-6.
2. Peppa M, Uribarri J, Vlassara H (2003) Glucose, advanced glycation end products, and diabetes complications: what is new and what works. Clin Diabetes 21(4): 186-187.

3. Zhicai Zhang, Feng-Jie Cui (2007) Non-enzymatic glycosylation reaction contributes to a rise of blood glucose in alloxan-induced diabetic rats Int J Diabetes and Metabolism 15: 52-59.

4. Ahmed N (2005) Advanced glycation end products role in pathology of diabetic complications. Diabetes Res Clin Pract 67(1): 3 -21.

5. Vitek MP, Bhattacharya K, Glendening JM, Stopa E, Vlassara H, et. al (1994) Advanced glycation end products contribute to amyloidosis in Alzheimer disease. Proc Natl Acad Sci U S A 91(11): 4766-4770.

6. Brownlee M (1995) Advanced protein glycosylation in diabetes and ageing. Annu Rev Med 46: 223-234.

7. Rahul C, Lincy J, Methew G, Pradhan P (2010) Pharmacognostic standardization and phytochemical screening of Albizzia lebbeck. J Chem Pharm Res 2(1):432-443.

8. Rimbau V, Cerdan C, Vila R, Iglesia J (1999) Anti-inflammatory activity of some extracts from plants used in traditional medicines of NorthAfrican Countries. Phytother Res 13(2): 128-132.

9. Sharma BK, Shamim A, Singh R (2012) A review on M. pruriens: its phytoconstituents and therapeutic uses. Novel Sci Int J Pharm Sci 1(6): 308-312.

10. Vaidya RA, Allorkar SD, Seth AR, Pandey SK (1978) Activity of bromoergocryptine, M. pruriens and L-Dopa in the control of hyperprolactenaemia. Neurology 26: 179-186.

11. Bhutkar MA, Bhise SB (2013) In vitro hypoglycemic effects of Albizzia lebbeck and Mucuna pruriens. Asian Pac J Trop Biomed 3(11): 866870 .

12. Fluckiger R, Winterhalter KH (1976) In vitro synthesis of hemoglobin. North-Holland Publishing Company, Amsterdam (71): p.354-356. 
This work is licensed under Creative Commons Attribution 4.0 License

DOI: 10.19080/GJPPS.2017.03.555624
Your next submission with Juniper Publishers will reach you the below assets

- Quality Editorial service

- Swift Peer Review

- Reprints availability

- E-prints Service

- Manuscript Podcast for convenient understanding

- Global attainment for your research

- Manuscript accessibility in different formats

( Pdf, E-pub, Full Text, Audio)

- Unceasing customer service

Track the below URL for one-step submission https://juniperpublishers.com/online-submission.php 